*Note:

Domestic abuse has multiple health consequences, several chronic and long-term ones. It also has intergenerational effects, ie, it affects the next generation. A woman who undergoes violence when pregnant, has a higher chance of miscarriage, stillbirth and other foetal health consequences. Children who grow up in households where domestic violence is a norm, have much higher likelihood of dropping out of school, mental and emotional development challenges. In National Family Health Survey (NFHS) of India (2015-16), data showed that for all women who said they were themselves suffering abuse at the hands of their husbands, 58 percent said they had grown up seeing their mothers getting beaten by their fathers. Violence commonly becomes normalised in such scenarios and even women start justifying it. In NFHS (2015-16), 52 percent women, compared to 42 percent men, justified wife-beating. The spiral of violence implicates generations.

\title{
The Liquid Miscreant
}

\author{
AISWARYA SASI
}

\section{Introduction}

Alcoholism is a social issue that cannot be undermined in today's setting. This work aims to plunge readers into the plight of the direct and indirect victims of alcohol abuse.

In the second year of medical college, I began my clinical postings. The posting that has had the biggest impact for me thus far was my psychiatry posting. In the course of just one week, I had lent my ears to myriad stories, each one more soul-stirring than its predecessor.

One Tuesday morning, the second day of our posting, I peeped into ward after ward, looking for a patient to speak to. The sole inhabitant of one of the wards was a plump little boy. Wrought with curiosity, I thought about taking his history, but dismissed the thought at once. He was only a little boy and I wasn't entirely sure how I would go about talking to him. Just as I made my way to the next ward, a cheery voice called out, "Doctor!" I peeped into the ward again, and the boy beckoned to me. His grandmother was sitting with him on the bed and chided, "Don't trouble akka, she must be busy!" The little boy smiled. "He was just bored. Sorry for disturbing you," she said to me."No that's alright," I

Author: Aiswarya Sasi (aiswarya.s@stjohns.in), Medical Intern, St John's Medical College Hospital, Koramangala, Bengaluru, 560034 INDIA.

To cite: Sasi A. The Liquid Miscreant. Indian J Med Ethics. 2021 Oct-Dec; 6(4) NS: 330-31. DOI: 10.20529/IJME.2021.033.

Published online on May 1, 2021.

Manuscript Editor: Rakhi Ghoshal

(c) Indian Journal of Medical Ethics 2021 said. I almost told her that as medical students, we had nothing to be busy with in the wards, and that I was glad to finally have something to do; instead, I just smiled at the two of them.

"What's your name?" I asked him. "My name is Mahesh," he said brightly. He chattered on happily for some time about nothing in particular. As soon as his mother entered the room, in a fraction of a second, his demeanour was transformed. The smile was now replaced by a frown and he stopped talking. His mother sat down. I introduced myself to his mother and asked her why he had been brought to the hospital. "He's a nuisance," she said expressionlessly. "He disturbs the class, doesn't study and doesn't let anybody else study. His marks are pathetic and he's quite useless. The doctors have diagnosed him with Attention Deficit Hyperactivity Disorder." Mahesh was quiet, obviously listening to his mother's words. "It's such a pain for me. I have to come here before going to work to bring his food and it's so far away." She sounded exhausted. She went on to scold him for something, in response to which he called her a 'dummi', or a 'fat person'. His mother left in the next few minutes. The moment she left, he was lively and cheerful again.

"He doesn't get along with his mother," his grandmother explained. "Mahesh, you shouldn't call your mother a dummi, that's not a good habit," I said to him. "I don't like her," he said curtly. "Can I talk to him outside for a while?" I asked his grandmother and she obliged without a second thought. As we walked out of the ward, I asked him why he didn't like his mother. "She is always saying bad things about me. After my father comes home and beats her, she becomes sad and she cries and if I ask her anything, she beats me. She makes me eat dinner very early - at $6 \mathrm{pm}$, and she makes me eat really fast, before my father gets home. If I ask for more, or if I tell her I'm 
hungry later, she yells at me." He spoke with a maturity that was sadly beyond his years.

"Why does your father beat your mother?" I asked softly. "After he drinks, he loses his mind. He takes all the money at home and buys alcohol with it - that's why we are so poor. And when he comes back home, he beats my mother. He has been doing it for many years. One time, my mother could not take it anymore and she left home. When she left, she took only my younger brother with her and just left me. She came back after a month. I could never look at her the same way after she abandoned me." I felt a tear coming to my eye, but forced it to disappear.

"How old are you?" "I'm nine years old," he said. He continued without any further prompting, "My brother is very smart. He studies very well and always comes first in his class. But he is too small to understand what is happening at home. I get very angry with my father when he beats my mother, but if I try to stop him, he beats me also. I can't study in my house because there is always so much noise. That's why I don't get good marks in school like my brother. My father got in an accident once, after he drank and then rode his bike. He had a head injury and he barely survived; we all thought he would stop drinking after that. But he didn't. He continued even after that..." At that moment, Mahesh did not seem like a nine- year-old. This little boy's childhood had been robbed by alcohol and its sequelae- an addicted father, an abused mother who took out her frustrations on him, and an unhappy, crumbling home.

Mahesh's story was just one of many. At the end of my brief interview with him, I could not figure out who or what was to be blamed. Who was really the victim here?

\section{Acknowledgement}

This was written as a part of the Reflective Narrative programme organised by the Health and Humanities Division of St. John's Research Institute.

\section{If you are looking for India's finest medical journal, then here it is.}

The National Medical Journal of India is a premier bi-monthly multi-disciplinary health sciences journal which publishes original research, reviews, and other articles relevant to the practice of medicine in India. The journal aims to instruct, inform, entertain and provide a forum for the discussion of social, economic and political health issues. It is included in the Index Medicus, (MEDLINE), Excerpta Medica (EmBase), BIOSIS, Current Contents/Clinical Medicine and Science Citation Index.

\begin{tabular}{|c|c|c|c|c|}
\hline \multicolumn{5}{|c|}{ SUBSCRIPTIONS } \\
\hline & One year & Two years & Three years & Five years \\
\hline India & Rs. 800 & Rs. 1500 & Rs. 2200 & Rs. 3600 \\
\hline Overseas & US $\$ 100$ & US \$180 & US \$ 270 & US \$ 450 \\
\hline
\end{tabular}

Personal subscriptions paid from personal funds are available at $50 \%$ discounted rates

Bank draft/cheques should be made in favour of The National Medical Journal of India. Journals can be sent by registered post on request at an added cost of Rs 90 per annum. Requests to be made at the time of subscribing.

Tel:91-11-26588802 Fax:91-11-26588663 E-mail:nmji@nmji.in Website:www.nmji.in

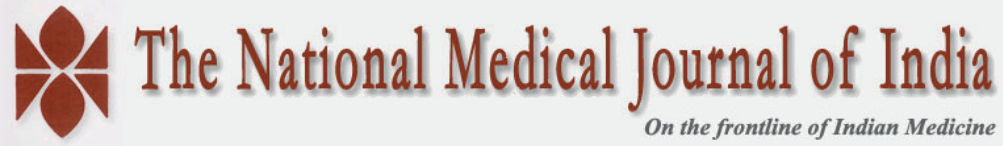

